\title{
AOX MITIGATION IN PULP BLEACHING EFFLUENTS USING ELEMENTAL CHLORINE FREE BLEACHING
}

\author{
P.Kumar ${ }^{1, *}$, S. Kumar ${ }^{2}$ and N. K. Bhardwaj ${ }^{3}$ \\ ${ }^{1}$ School of Basic \& Applied Sciences, G D Goenka University, Sohna -122413, (Haryana) India \\ ${ }^{2}$ Department of Paper Technology, IIT Roorkee, Saharanpur-247001, (U.P.) India \\ ${ }^{3}$ Avantha Centre for Industrial Research \& Development, \\ Yamuna Nagar -135001, (Haryana) India \\ *E-mail: praveen.kumar1@gdgu.org
}

\begin{abstract}
The pulping and bleaching are two major processes of prime environmental concern during paper manufacture due to the generation of highly polluted effluents. The bleaching is aimed at removing the residual lignin to achieve desired pulp brightness. $\mathrm{Cl}_{2}$ or chlorine-based bleaching chemicals generate a variety of chlorinated organics, measured collectively as adsorbable organic halides (AOX), in the bleaching effluents. The disposal of bleaching effluents containing AOX poses an enormous threat to the aquatic organisms and public health. The environmental concern has led to the substitution of $\mathrm{Cl}_{2}$ based conventional bleaching with elemental chlorine-free (ECF) and chlorine-free (TCF) bleaching to regulate AOX generation in the effluents. The present study is aimed at reducing AOX generation in the bleaching effluent by using eco-friendly ECF bleaching technology (i.e. replacement of elemental chlorine with $\mathrm{ClO}_{2}, \mathrm{H}_{2} \mathrm{O}_{2}$ reinforced alkaline extraction and $\mathrm{O}_{2}$ delignification). The mixed hardwood kraft pulp is bleached to $87 \%$ ISO target brightness using $\mathrm{D} / \mathrm{CED}, \mathrm{DED}, \mathrm{DE} \mathrm{P}$, and ODED sequences under the controlled laboratory conditions. The ECF bleaching sequences $(0.67,0.55$, and $0.34 \mathrm{~kg} / \mathrm{t}$ OD pulp for DED, DE $\mathrm{D}$, and ODED, respectively) can reduce AOX generation below the set regulatory standard (1 Kg/T OD pulp) as compared to D/CED sequence ( $2.6 \mathrm{~kg} / \mathrm{t}$ OD pulp). ODED sequence saved $45 \%$ bleach chemical as compared to the $\mathrm{D} / \mathrm{CED}$ sequence. The ECF bleaching sequences can cut $\mathrm{NaOH}$ dose by $30 \%$ during the alkaline extraction $\left(\mathrm{E} / \mathrm{E}_{\mathrm{P}}\right)$ stage as compared to $\mathrm{D} / \mathrm{CED}$ sequence. ODED and $\mathrm{DE} \mathrm{P}$ bleaching sequences are found appropriate to meet the AOX discharge standard.
\end{abstract}

Keywords: AOX, ECF, Bleaching, $\mathrm{O}_{2}$ Delignification, Pulp, Economic Analysis.

(C) RASĀYAN. All rights reserved

\section{INTRODUCTION}

The pulping and bleaching are two major processes during pulp and paper manufacture from wood or other lignocellulosic raw materials. They are of prime environmental concern due to the generation of highly polluted effluent streams. The considerable increase in awareness about the environmental impacts of pulp bleaching effluents during past decades has resulted in stricter statutory norms. This is a driving force that is moving the pulp and paper industry towards sustainability. The cleaner processes are being adopted to reduce the impact on the natural environment. The lignin which keeps cellulose fibers bound together in wood is an undesirable material during pulp and paper manufacture. The chemical pulp production involves the dissolution of a significant part of lignin by cooking wood chips at high temperature and pressure with chemicals. The pulp produced after pulping still contains residual lignin (2$5 \%)^{1}$. The residual lignin produces unwanted dark color and causes photo-yellowing of pulp. The bleaching is aimed to remove the residual lignin to improve pulp brightness for the production of white paper. Bleaching improves the pulp brightness by either lignin removal or decolourization ${ }^{2}$ with various chlorine or oxygen-based chemicals (oxidants). The bleaching is carried out in multiple stages for better chemical efficiency and protection of pulp strength. The individual pulp bleaching stages follow intermediate alkaline $(\mathrm{NaOH})$ extraction stage which dissolves and remove lignin degradation products. $\mathrm{Cl}_{2}$ or chlorine-based chemicals used for bleaching generate a variety of chlorinated organics (chlorinated hydrocarbons, phenols, guaiacols, vanillins, resin acids, fatty acids, syringols, catechols, furans, and

Rasayan J. Chem., 13(2), 1262-1270(2020)

http://dx.doi.org/10.31788/RJC.2020.1325408

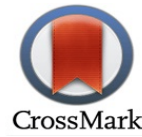


RASĀYAN J. Chem.

Vol. 13 | No. 2 |1262-1270| April - June | 2020

dioxins etc.) in the bleaching effluents which are estimated as adsorbable organic halides (AOX) $)^{3,4}$. The residual lignin left in the pulp after pulping is assumed to be the major cause of AOX generation ${ }^{5}$. AOX generation is directly proportional to the consumption of $\mathrm{Cl}_{2}$ or chlorine derived bleach chemicals ${ }^{6}$ and is influenced by the pulp's hexenuronic acid and hemicellulose content ${ }^{7,8}$. The pulp and paper sector is one of the biggest users of water and generate about $20-100 \mathrm{~m}^{3}$ of effluent per metric ton of paper'. The effluent is characterized with high load of biochemical oxygen demand (BOD: 14-18 kg/t), chemical oxygen demand (COD: $25-40 \mathrm{~kg} / \mathrm{t}$ ), colour, chlorinated organics (AOX: 0-4 kg/t of pulp), suspended solids (SS: $10-15 \mathrm{~kg} / \mathrm{t})$, nitrogen $(400-600 \mathrm{~g} / \mathrm{t})$, and phosphorus $(100 \mathrm{~g} / \mathrm{t})^{10-12}$. The hardwood pulps are reported to generate a lower amount of AOX (3-5 kg/t pulp) as compared to softwood pulps $(5-10 \mathrm{~kg} / \mathrm{t}$ pulp) ${ }^{13}$.

The discharge of bleaching effluents containing AOX poses an enormous threat to the aquatic organisms and human health. Chlorinated organics are bio-recalcitrant, carcinogenic, mutagenic, and toxic. They show long-distance mobility and bio-magnify through food chains to affect organisms at different trophic levels ${ }^{14,15}$. Chlorine substitution of natural substances during bleaching decreases reactivity, water solubility, and increases the persistence of resultant compounds. This increases the bio-concentration potential of the compound into living tissues with greater toxicity ${ }^{16}$. The effluents from the paper industry are found to affect liver function, reduce gonad size, depress sex steroids, and affect the development of ovaries in fish ${ }^{17}$. The dark color and turbidity of effluent affect photosynthesis and bottom-feeding organisms in the aquatic ecosystems.

The paper industry is encouraged to upgrade and implement cleaner technologies to meet stricter environmental regulations and ensure global competitiveness in terms of the use of energy, fuel, and chemicals. The Central Pollution Control Board (India) has set an effluent discharge standard for AOX generation as $1 \mathrm{~kg} / \mathrm{t}$ of paper produced with effect from $1^{\text {st }}$ March 2008 for large pulp and paper industry $(>24,000 \mathrm{MT} / \text { annum })^{18}$. The environmental concern about the discharge of AOX in bleaching effluents has led to the substitution of $\mathrm{Cl}_{2}$ based conventional bleaching with elemental chlorine $\left(\mathrm{Cl}_{2}\right)$ free $(\mathrm{ECF})$ and total chlorine-free $\left(\mathrm{H}_{2} \mathrm{O}_{2}\right.$ and $\mathrm{O}_{3}$ etc.) (TCF) technologies ${ }^{19}$. The ECF bleached pulp (employing $\mathrm{ClO}_{2}$ ) has dominated the world market (production 10 times of TCF) and demand continues to increase. The modern trend is towards a replacement of $\mathrm{Cl}_{2}$ with $\mathrm{ClO}_{2}$ to produce ECF pulp. The well-managed ECF pulp and paper industries are reported to have a negligible impact on aquatic ecosystems due to the absence of persistent and toxic organics in treated water ${ }^{2}$. Yang et al.(2017) ${ }^{20}$ reported a significant reduction (1.3-14.9 times) in the generation of polychlorinated dioxins and furans by substitution of $\mathrm{Cl}_{2}$ bleaching by $\mathrm{ClO}_{2}$ during a field investigation in a non-wood pulp and paper industry. Kaur et al. $(2017)^{21}$ studied $\mathrm{ClO}_{2}$ bleaching of rice straw pulp and reported $66 \%$ reduction in generation of AOX as compared with $\mathrm{Cl}_{2}$ based bleaching sequences. $\mathrm{ClO}_{2}$ based bleaching can improve effluent quality and decrease the volume of effluent by $30 \%$ as compared with $\mathrm{Cl}_{2}$ bleaching ${ }^{22}$. The present study is aimed at reducing AOX generation in the bleaching effluents by using eco-friendly ECF bleaching technology. The process of economic analysis is also carried out to determine the appropriate bleaching sequence.

\section{EXPERIMENTAL}

\section{Materials}

$\mathrm{NaClO}_{2}$ solution $(40 \mathrm{~g} / \mathrm{L})$ is used for in-situ generation of chlorine dioxide (D or D/C stage). The alkaline extraction $\left(\mathrm{E}\right.$ or $\mathrm{E}_{\mathrm{P}}$ ) stage is conducted using a solution of $\mathrm{NaOH} . \mathrm{H}_{2} \mathrm{O}_{2}(30 \%)$ solution is used for peroxide reinforced alkaline extraction of pulp $\left(\mathrm{E}_{\mathrm{P}}\right.$ stage) along with $\mathrm{NaOH}$ solution. The $\mathrm{pH}$ of the pulp is adjusted with $\mathrm{NaOH}$ or $\mathrm{H}_{2} \mathrm{SO}_{4}$ solutions (1M). The chlorine bleach liquor $(\mathrm{D} / \mathrm{C}$ stage) and unbleached mixed hardwood (Eucalyptus: Poplar, 70:30) kraft pulp (Kappa number: 15, brightness: 34.5\% ISO, and viscosity: $13.9 \mathrm{cP}$ ) are received from a pulp and paper industry. The paper industry uses $\mathrm{OCE}_{\mathrm{P}} \mathrm{HH}$ bleaching sequence. The pulp is hand washed on a screen, air dried, and kept stored in plastic bags to be used for bleaching.

\section{Pulp Bleaching}

The pulp is bleached to a target brightness of $87 \%$ ISO following $\mathrm{D} / \mathrm{CED}, \mathrm{DE} \mathrm{P}_{\mathrm{P}} \mathrm{D}, \mathrm{DED}$, and ODED sequences under the controlled laboratory conditions (Table-1). The active chlorine multiple $\left(\mathrm{aCl}^{-}\right)$ required for pulp bleaching is estimated using the following equation: 
RASĀYAN J. Chem.

Vol. 13 | No. 2 |1262-1270| April - June | 2020

Chlorine demand $\left(\% a \mathrm{Cl}^{-}\right)=$Kappa no. $\times$Kappa factor

The $70 \%$ of the bleach chemical charge is given in $\mathrm{D}_{1}$ or $\mathrm{D} / \mathrm{C}$ (first) stage and $30 \%$ in $\mathrm{D}_{2}$ (last) stage. All the experiments are performed in polythene bags except $\mathrm{D} / \mathrm{C}$ stage which is carried out into plastic containers at room temperature with $200 \mathrm{~g}$ O.D. unbleached pulp. All the bleaching stages are carried out at $10 \%$ consistency except $\mathrm{D} / \mathrm{C}$ stage $(3 \%)$. The disintegrated pulp is first adjusted to the desired consistency and $\mathrm{pH}$. This is followed by bleach chemicals addition, hand mixing, and placing in the water bath at the desired temperature. The pulp is well mixed by hand (poly bags) or shaking the bottle $(\mathrm{D} / \mathrm{C}$ stage) throughout the bleaching. The pulp slurry is filtered and washed with distilled water after completion of bleaching using a Buchner funnel. The filtrate and washings are mixed before characterization (Fig.-1). All bleaching experiments are carried out in duplicate and average values reported.

Table-1: Pulp Bleaching Experimental Conditions

\begin{tabular}{|c|c|c|c|c|c|c|c|c|c|c|c|c|c|}
\hline \multirow{2}{*}{ Parameters } & \multicolumn{3}{|c|}{$\mathrm{D} / \mathrm{CED}$} & \multicolumn{3}{|c|}{$\mathrm{DE}_{\mathrm{p}} \mathrm{D}$} & \multicolumn{3}{|c|}{ DED } & \multicolumn{4}{|c|}{ ODED } \\
\hline & $\mathrm{D}_{50} / \mathrm{C}_{50}$ & $\mathrm{E}$ & $\mathrm{D}$ & $\mathrm{D}_{1}$ & $\mathrm{E}_{\mathrm{P}}$ & $\mathrm{D}_{2}$ & $\mathrm{D}_{1}$ & $\mathrm{E}$ & $\mathrm{D}_{2}$ & $\mathrm{O}$ & $\mathrm{D}_{1}$ & $\mathrm{E}$ & $\mathrm{D}_{2}$ \\
\hline $\mathrm{a} \mathrm{Cl}^{-}$Applied (\%) & $\begin{array}{c}3.15 \\
(50 / 50)\end{array}$ & - & 1.35 & 3.15 & - & 1.35 & 3.68 & - & 1.57 & - & 1.74 & - & 0.75 \\
\hline Residual $\mathrm{aCl}^{-}(\%)$ & Nil & - & 0.23 & Nil & - & 0.04 & Nil & - & 0.03 & - & Nil & - & Nil \\
\hline $\mathrm{NaOH}(\%)$ & - & 1.0 & - & - & 0.7 & - & - & 0.7 & - & 2.0 & - & 0.7 & - \\
\hline $\begin{array}{l}\mathrm{O}_{2} \text { Pressure } \\
\left(\mathrm{kg} / \mathrm{cm}^{2}\right)\end{array}$ & - & - & - & - & - & - & - & - & - & 6 & - & - & - \\
\hline $\mathrm{H}_{2} \mathrm{O}_{2}(\%)$ & - & - & - & - & 0.3 & - & - & - & - & - & - & - & - \\
\hline $\mathrm{MgSO}_{4} .7 \mathrm{H}_{2} \mathrm{O}(\%)$ & - & - & - & - & - & - & - & - & - & 0.2 & - & - & - \\
\hline Temperature $\left({ }^{\circ} \mathrm{C}\right)$ & $\begin{array}{c}\text { Ambie } \\
n t\end{array}$ & 70 & 70 & 70 & 70 & 70 & 70 & 70 & 70 & 100 & 70 & 70 & 70 \\
\hline Time (min) & 45 & 90 & 180 & 180 & 90 & 180 & 180 & 90 & 180 & 75 & 180 & 90 & 180 \\
\hline End $\mathrm{pH}$ & 2.0 & $\begin{array}{c}10 . \\
5\end{array}$ & 3.5 & 3.5 & 10.5 & 3.3 & 3.4 & 11.5 & 3.5 & - & 3.5 & 11.4 & 3.2 \\
\hline
\end{tabular}

\section{Analysis}

The pulp brightness is measured using TECHNIBRITE ERIC 950 (Technibrite Corporation, USA). The pulp viscosity is measured by the capillary viscometer method using $1 \mathrm{M}$ cupriethylenediamine (CED) solution. The strength of $\mathrm{NaClO}_{2}$ or $\mathrm{Cl}_{2}$ bleach liquor, as active chlorine $\left(\mathrm{aCl}^{-}\right)$, is determined by titrating against a standard solution of $0.1 \mathrm{~N} \mathrm{Na}_{2} \mathrm{~S}_{2} \mathrm{O}_{3}$ using starch $(0.5 \%)$ as an indicator. $10 \mathrm{~mL} \mathrm{KI}(10 \%)$ and 10 $\mathrm{mL}$ acetic acid $(10 \%)$ is added to $10 \mathrm{~mL}$ of diluted bleach liquor and the resulting solution is titrated against standard $\mathrm{Na}_{2} \mathrm{~S}_{2} \mathrm{O}_{3}$ solution. The endpoint is blue to colorless. The strength of the bleach liquor is calculated using the following formula:

Strength of bleach liquor $(\mathrm{g} / \mathrm{l})=$ Normality of bleach liquor $\times 34.5$

The residual chlorine in the spent bleach liquor is determined by taking $100 \mathrm{~mL}$ of spent bleach liquor following the same procedure ${ }^{23}$. The pulp bleaching effluents are characterized for AOX using a column method with an AOX analyzer (ECS 1200).

\section{RESULTS AND DISCUSSION}

The mitigation of bio-recalcitrant and hazardous compounds in the paper industry effluents can be achieved through either adoption of eco-friendly manufacturing technologies or end-of-pipe effluent treatment. The use of eco-friendly ECF bleaching technologies has gained momentum during past decades as an effective approach for at source mitigation of AOX generation. Hence, ECF bleaching (DED, $\mathrm{DE}_{\mathrm{P}} \mathrm{D}$, and ODED) of hardwood kraft pulp has been investigated as compared with $\mathrm{Cl}_{2}$ bleaching (D/CED), with $50-100 \%$ substitution of $\mathrm{Cl}_{2}$ by $\mathrm{ClO}_{2}$, for reduction of $\mathrm{AOX}$ generation in the bleaching 
RASĀYAN J. Chem.

Vol. 13 | No. 2 |1262-1270| April - June | 2020

effluents. The $\mathrm{O}_{2}$ pre-delignification and $\mathrm{H}_{2} \mathrm{O}_{2}$ application during alkaline extraction are also studied for the reduction of AOX generation during ECF bleaching. The $\mathrm{O}_{2}$ delignification is targeted for $40-50 \%$ reduction in kappa number with a minimum drop in pulp viscosity. Almost 45\% kappa number reduction is achieved with $12 \%$ viscosity drop at an optimum $\mathrm{NaOH}$ dose of $20 \mathrm{~kg} / \mathrm{t}$ O.D. pulp in our previous study $^{24} . \mathrm{O}_{2}$ is poorly selective at a high degree of delignification and may lead to a reduction in pulp quality and yield, if used extensively, by carbohydrate degradation ${ }^{25}$.

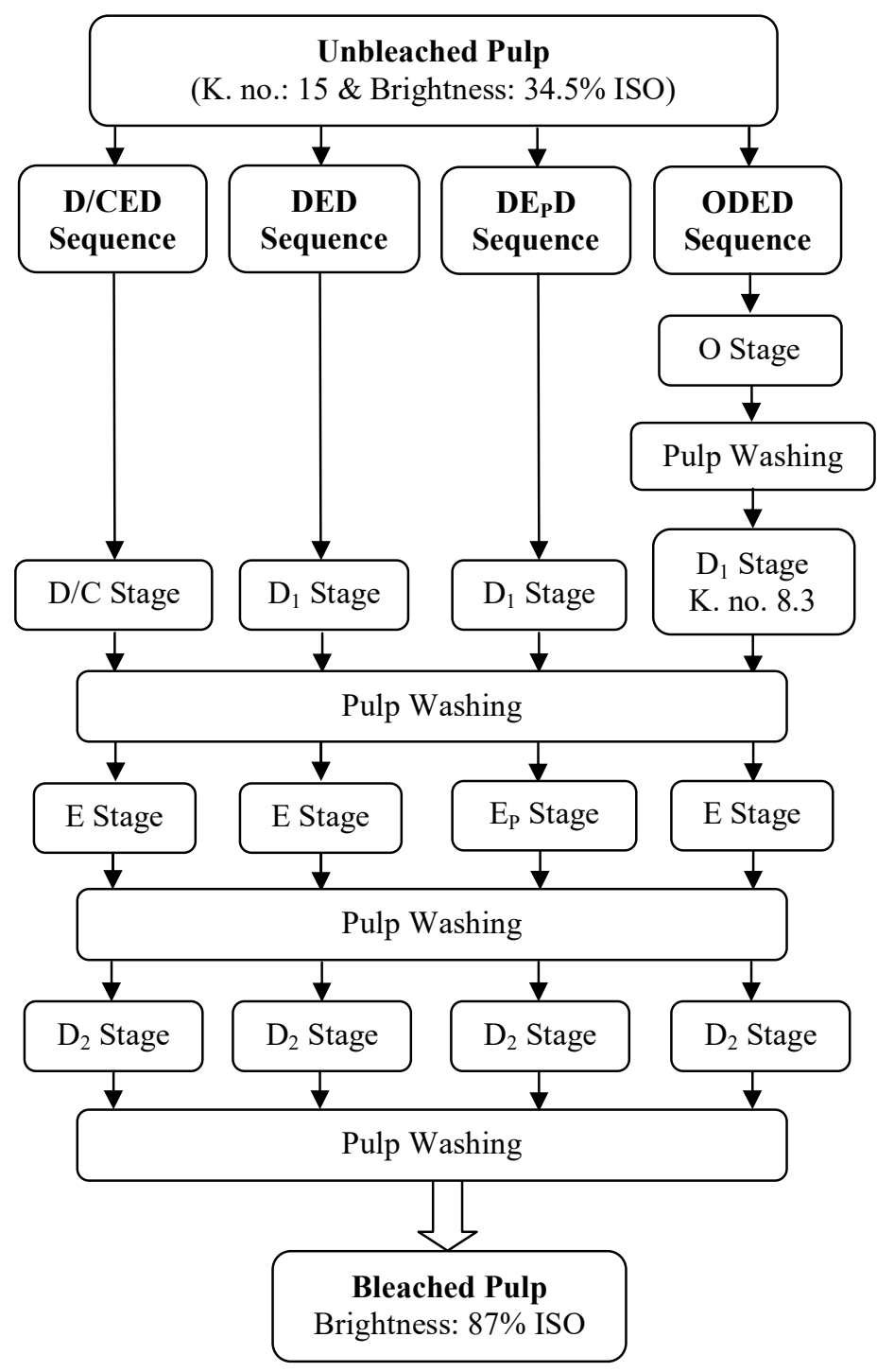

Fig.-1: The Pulp Bleaching Sequences Flow Chart

\section{Chlorine Demand Optimization}

The optimum chlorine $\left(^{-} \mathrm{Cl}^{-}\right.$) demand required to achieve 87\% ISO target pulp brightness through $\mathrm{D} / \mathrm{CED}, \mathrm{DED}, \mathrm{DE} \mathrm{P}$, and ODED bleaching sequences is found by varying kappa factor $(\mathrm{KF})$ from 0.28 0.35 (Figure 2). A KF of 0.35 is found to be optimum for the DED sequence as compared with other sequences (KF 0.3). $\mathrm{ClO}_{2}$ is much less effective at $100 \%$ substitution with low final brightness, hence a higher KF (bleach chemical charge) is needed to achieve the same target brightness ${ }^{26} . \mathrm{H}_{2} \mathrm{O}_{2}$, an ecofriendly oxidizing agent, participates in additional lignin oxidation reactions during alkaline extraction $(\mathrm{E})$ stage of the $\mathrm{DE}_{\mathrm{P}} \mathrm{D}$ bleaching sequence and thus a lower $\mathrm{KF}(0.3)$ is required for a given target brightness. The $\mathrm{O}_{2}$ pre-delignification stage reduced the initial kappa number of the pulp by $45 \%$. Hence, a lower KF $(0.3)$ is found optimum for the ODED bleaching sequence for the same target brightness. 
RASĀYAN J. Chem.

Vol. 13 | No. 2 |1262-1270| April - June | 2020

\section{AOX Mitigation}

The major AOX load came from the first two bleachings ( $D / C$ or $D_{1}$ and $E$ or $E_{\mathrm{P}}$ ) stages for all the bleaching sequences (Table 3). The large quantity of organic material solubilized during chlorination and alkaline extraction stages, during kraft pulp bleaching ${ }^{27}$. The increase in no of free phenolic hydroxyl and carboxyl groups and decreased molecular weight improve the solubility of lignin during following alkaline extraction stage. The highest amount of AOX is generated in D/CED sequence $\left(50 \% \mathrm{ClO}_{2}\right.$ and $\left.50 \% \mathrm{Cl}_{2}\right)$ effluents $(2.60 \mathrm{~kg} / \mathrm{t}$ O.D. pulp) as compared to DED, $\mathrm{DE}$ D, and ODED sequences $(100 \%$ $\mathrm{ClO}_{2}$ ). The pulp chlorination involves the binding of about $10 \%$ of chlorine applied to residual lignin to form chlorinated organics while the remainder $(90 \%)$ is converted into chloride ion ${ }^{28}$.

AOX generation in the effluent has been reported to decrease by $40-60 \%$ with $45-100 \%$ chlorine demand substitution by $\mathrm{ClO}_{2}{ }^{29}$. $\mathrm{ClO}_{2}$ has five times higher oxidation power as compared to $\mathrm{Cl}_{2}$. The proportion of oxidative reactions increases by application of $\mathrm{ClO}_{2}$. This results in decreased generation of chloroorganics in the effluent ${ }^{3,30}$. The DED sequence is found to generate higher AOX in effluents $(0.67$ $\mathrm{kg} / \mathrm{t}$ O.D. pulp) as compared to $\mathrm{DE}_{\mathrm{P}} \mathrm{D}$ and ODED sequences. This is due to the requirement of higher $\mathrm{KF}$ for achieving the same target brightness. $\mathrm{ClO}_{2}$ is much less effective at $100 \%$ substitution, often resulting in higher CE lignin content and lower final brightness. Hence, the requirement of higher bleach chemical charge results in the generation of higher AOX in the effluent as compared with $\mathrm{DE}_{\mathrm{P}} \mathrm{D}$ and ODED sequences ${ }^{26} \cdot \mathrm{H}_{2} \mathrm{O}_{2}$ is an environmentally friendly and strong oxidizing agent for bleaching ${ }^{31}$.

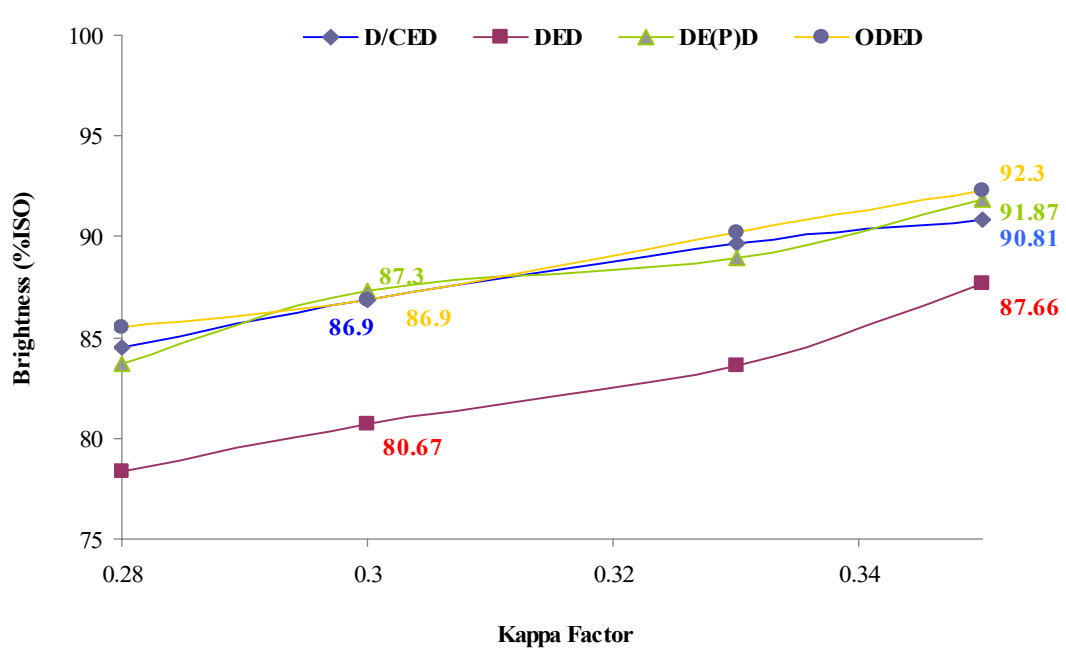

Fig.-2 Chlorine Demand Optimization to Achieve 87\% ISO Target Brightness for D/CED, DED, DE $\mathrm{P}$, and ODED Bleaching Sequences

Table-3: AOX Generation (Kg/t O.D. pulp) during Different Bleaching Sequences

\begin{tabular}{l|c|c|c|c}
\hline \multicolumn{1}{c|}{ Bleaching Stage } & D/CED & DED & DE & ODED \\
\hline $\mathrm{D} / \mathrm{C}$ or $\mathrm{D}_{1}$ & 2.20 & 0.32 & 0.27 & 0.16 \\
\hline $\mathrm{E}$ or $\mathrm{E}_{\mathrm{P}}$ & 0.30 & 0.28 & 0.23 & 0.14 \\
\hline $\mathrm{D} / \mathrm{D}_{2}$ & 0.10 & 0.07 & 0.05 & 0.04 \\
\hline Total & 2.60 & 0.67 & 0.55 & 0.34 \\
\hline
\end{tabular}

The application of $\mathrm{H}_{2} \mathrm{O}_{2}$ along with $\mathrm{NaOH}$ during E stage in the $\mathrm{DE}_{\mathrm{P}} \mathrm{D}$ sequence reduced the requirement of active chlorine multiple (KF 0.30) hence lower AOX is generated as compared to the DED sequence. $\mathrm{H}_{2} \mathrm{O}_{2}$ addition in $\mathrm{E}$ stage decreased the lignin content further by additional oxidation and thus allowed the $\mathrm{KF}$ for a given kappa target to be lowered. Hence, AOX generation in effluents decreased because of less chlorine demand in the first bleaching stage ${ }^{32}$. ODED sequence effluents are found to be having the lowest AOX load $(0.34 \mathrm{Kg} / \mathrm{t}$ O.D. pulp) as compared to other sequences. This is because of the decrease $(45 \%)$ of the initial kappa number of the pulp after $\mathrm{O}_{2}$ delignification. This reduces $\mathrm{aCl}^{-}$demand needed for the subsequent bleaching stages and AOX load ${ }^{3}$. The pulp with a lower kappa number can be bleached more easily, and the bleach chemicals consumption and the pollution load can be minimized ${ }^{33}$. 
RASĀYAN J. Chem.

Vol. 13 | No. 2 |1262-1270| April - June | 2020

\section{Economic Analysis}

The dose of various chemicals applied during different pulp bleaching sequences is summarized in Table4. The total active chlorine consumption followed the order: $\mathrm{DED}>\mathrm{D} / \mathrm{CED}=\mathrm{DE} \mathrm{P}>\mathrm{ODED}$ to achieve same target brightness of $87 \%$ ISO (Fig.-3).

Table-4: Chemical Dose (Kg/t O.D. pulp) Applied During Pulp Bleaching

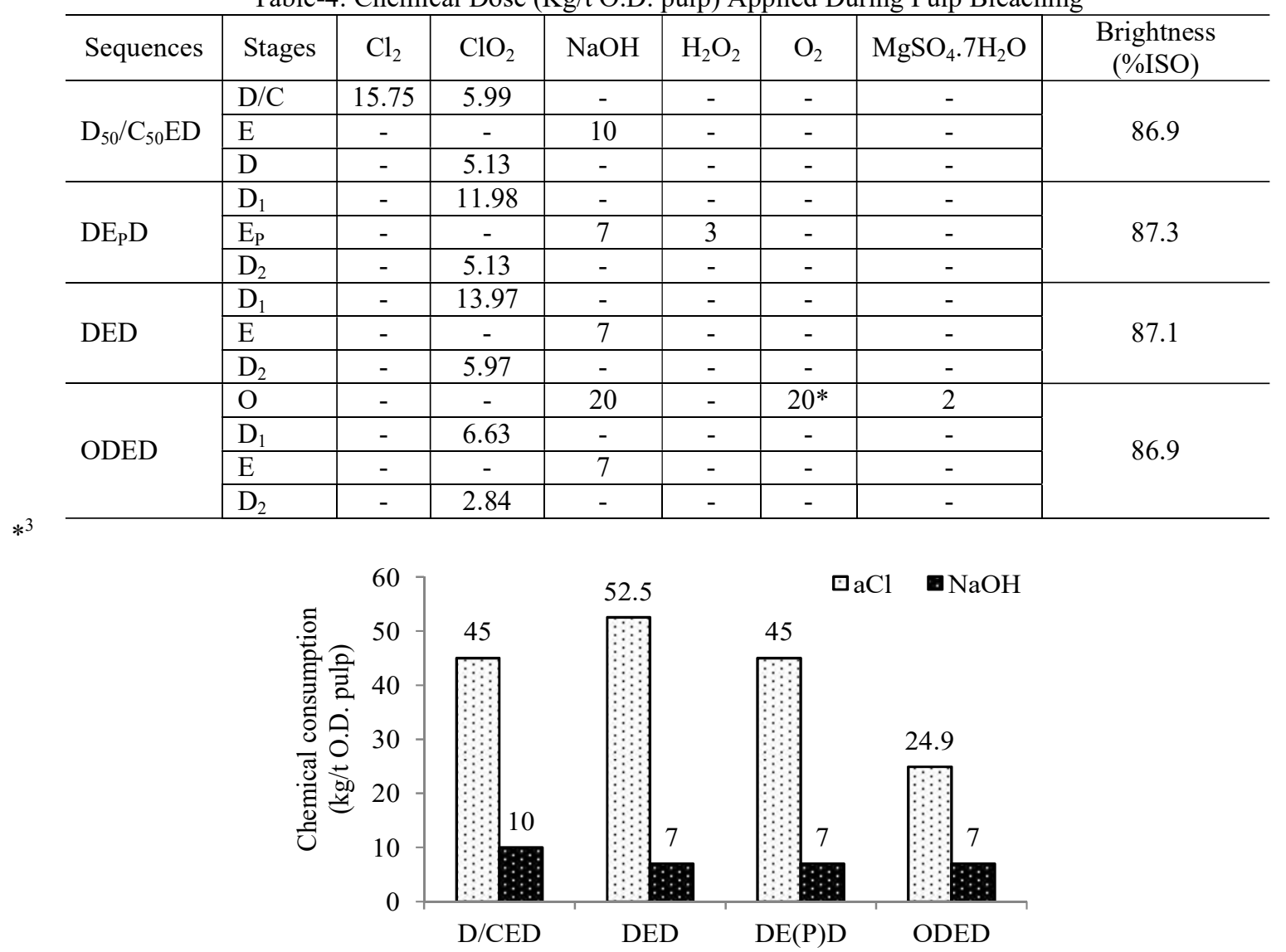

Fig.-3: Chemical Consumption During Pulp Bleaching Sequences

The application of the $\mathrm{O}_{2}$ delignification stage in the ODED sequence can reduce bleach $\left(\mathrm{aCl}^{-}\right)$chemical dose by $53 \%$ as compared to the DED sequence and $45 \%$ as compared to $\mathrm{D} / \mathrm{CED}$ and $\mathrm{DE}_{\mathrm{p}} \mathrm{D}$ sequences. DED sequence required 14\% higher bleach $\left(\mathrm{aCl}^{-}\right)$chemical dose to achieve $87 \%$ ISO target brightness as compared to $\mathrm{D} / \mathrm{CED}$ and $\mathrm{DE}_{\mathrm{P}} \mathrm{D}$ sequences. There is required $30 \%$ less $\mathrm{NaOH}$ dose during bleaching with ECF (DED, DE $\mathrm{P}$, and ODED) sequences as compared to the $\mathrm{D} / \mathrm{CED}$ sequence. There has been reported a reduction in alkali charge during E stage during ECF bleaching sequences ${ }^{26}$. The reduction of chemical requirements for pulp bleaching is important for process economy as well as for environmental protection.

The economic analysis of any process change can be assessed by considering operating cost or value addition. However, the economic value calculation is difficult for intangible benefits. The improved environmental performance, in such cases, can be considered for the assessment of process economic viability.

The process may face closure due to non-compliance with set statutory norms. Under such circumstances, the additional input costs for making the process operation can be considered as an investment cost and cost of closure due to non-compliance as an economic gain of investment. The bleaching economic analysis has been carried out by considering the costs associated with the following factors: ${ }^{34}$

- The bleach chemical costs for different sequences (Table-5) as per 2018. 
RASĀYAN J. Chem.

Vol. 13 | No. 2 |1262-1270| April - June | 2020

- AOX abatement costs: by bleaching modification and effluent treatment (adsorption and ion exchange: Rs 200/kg of AOX removed) have been considered as additional operating costs for meeting the regulatory standards.

- The intangible benefits, environmental compliance by bleaching modification, which would otherwise have been closed due to non-compliance, are not considered.

- The cost savings by alkali recovery from $\mathrm{O}_{2}$ stage effluent recycling have not been considered, which will further reduce the cost of the ODED sequence.

The economic analysis of various pulp bleaching sequences as compared with the D/CED sequence is summarized in Table 6. The cost of the DED sequence is found to be the highest (2274 Rs/t O.D. pulp) followed by ODED, $\mathrm{DE} \mathrm{P}_{\mathrm{P}} \mathrm{D}$, and $\mathrm{D} / \mathrm{CED}$ sequences due to the requirement of higher bleach chemical charge to attain the same target brightness. If the additional costs associated with AOX abatement at source (Rs 683/-, 580/-, and 596/- for DED, $\mathrm{DE}_{\mathrm{p}} \mathrm{D}$, and ODED sequences, respectively, as compared to $\mathrm{D} / \mathrm{CED}$ sequence) and effluent treatment of AOX (amount reduced at source as compared to D/CED sequence) using adsorption and ion exchange technologies (Rs. 200/kg AOX removed) ${ }^{35}$ are considered, then ODED sequence is found to be having Rs 144/- higher cost followed by $\mathrm{DE}_{\mathrm{P}} \mathrm{D}$ (Rs 170/-) and DED (Rs 297/-) sequences as compared to D/CED sequence. All ECF bleaching sequences (DED, DE $\mathrm{P}$, and ODED) can reduce AOX generation below the set regulatory standard $(1 \mathrm{~kg} / \mathrm{t}$ of paper for large pulp and paper industry $)^{18}$. DED sequence generated $74 \%$ lesser AOX as compared to the D/CED sequence.

Table-5: Cost of Chemicals (Rs/Kg) Used for Pulp Bleaching in India (2018)

\begin{tabular}{l|c}
\hline \multicolumn{1}{c|}{ Chemical } & Cost $(\mathrm{Rs} / \mathrm{kg})$ \\
\hline Chlorine $\left(\mathrm{Cl}_{2}\right)$ & 05 \\
\hline Chlorine Dioxide $\left(\mathrm{ClO}_{2}\right)$ & 100 \\
\hline Sodium Hydroxide $(\mathrm{NaOH})$ & 40 \\
\hline Hydrogen Peroxide $\left(\mathrm{H}_{2} \mathrm{O}_{2}\right)$ & 60 \\
\hline Oxygen $\left(\mathrm{O}_{2}\right)$ & 07 \\
\hline Magnesium Sulphate $\left(\mathrm{MgSO}_{4} \cdot 7 \mathrm{H}_{2} \mathrm{O}\right)$ & 10 \\
\hline
\end{tabular}

Table-6: Economic Analysis of Pulp Bleaching Sequences

\begin{tabular}{l|c|c|c|c|c|c|c}
\hline \multirow{2}{*}{ Sequence } & \multicolumn{2}{|c|}{$\begin{array}{c}\text { Bleaching Cost } \\
\text { (Rs/T O.D. pulp) }\end{array}$} & \multicolumn{2}{c|}{ AOX (kg/T O.D. Pulp) } & \multicolumn{3}{|c}{$\begin{array}{c}\text { AOX Abatement Cost } \\
\text { (Rs/kg) }\end{array}$} \\
\cline { 2 - 8 } & Pre-treatment & $\begin{array}{c}\text { Bleach } \\
\text { Chemical }\end{array}$ & Generation & $\begin{array}{c}\text { Reduction at } \\
\text { Source }\end{array}$ & $\begin{array}{c}\text { At } \\
\text { Source }\end{array}$ & ET* & Savings \\
\hline D/CED & - & 1591 & 2.60 & - & - & - & - \\
\hline DED & - & 2274 & 0.67 & 1.93 & +683 & 386 & -297 \\
\hline DE & - & 2171 & 0.55 & 2.05 & +580 & 410 & -170 \\
\hline ODED & 960 & $2187^{\#}$ & 0.34 & 2.26 & +596 & 452 & -144 \\
\hline
\end{tabular}

*Effluent treatment cost of AOX (which is reduced at source) $(200 \mathrm{Rs} / \mathrm{kg})^{35}$; \# including the cost of $\mathrm{O}_{2}$ pretreatment.

The pulp and paper industry may look at $\mathrm{O}_{2}$ pre-bleaching stage to meet AOX discharge standards and closing the bleach cycle with $\sim 87 \%$ lower AOX generation at Rs 144/- higher cost as compared to D/CED sequence. The high capital cost is one of the major causes of not adopting the $\mathrm{O}_{2}$ pre-delignification process, particularly in small industries. The pulp and paper industries which will not be able to install $\mathrm{O}_{2}$ pre-bleaching stage can meet up effluent $\mathrm{AOX}$ discharge standards by adopting a $\mathrm{DE} \mathrm{E}_{\mathrm{P}} \mathrm{D}$ sequence with 79\% lesser AOX generation at Rs 170/- higher cost as compared to D/CED sequence.

\section{CONCLUSION}

The following conclusions are drawn based on the results:

- All ECF bleaching sequences are found to decrease effluent AOX generation below the regulatory standard.

- The ECF bleaching sequences reduced alkali consumption by $30 \%$ as compared to the D/CED sequence. 
RASĀYAN J. Chem.

Vol. 13 | No. 2 |1262-1270| April - June | 2020

- The economic analysis shows that ODED and $\mathrm{DE}_{\mathrm{p}} \mathrm{D}$ sequences can be adopted concerning meeting AOX discharge standards. $\mathrm{DE} P \mathrm{P}$ sequence is an alternative for the pulp and paper industries where $\mathrm{O}_{2}$ plant installation is not possible.

\section{ACKNOWLEDGMENT}

The authors appreciate the financial grant from the Ministry of Human Resource Development, Government of India for the successful completion of this study.

\section{REFERENCES}

1. H. L. Hintz and S. A. Lawal, Elsevier Inc, (2018), DOI:10.1016/B978-0-12-803581-8.11233-0.

2. P. Bajpai, Biermann's Handbook of Pulp and Paper (Third Edition), Volume 1: Raw Material and Pulp Making, pp.465-491 (2018), DOI: 10.1016/B978-0-12-814240-0.00019-7.

3. C. W. Dence and D. W. Reeve, Pulp Bleaching - Principles and Practice, TAPPI Press, Atlanta, Georgia, 227, 752 (1996).

4. P. Sharma, C. Sood, G. Singh and N. Capalash, Journal of Cleaner Production, 87, 966(2015), DOI:10.1016/j.jclepro.2014.09.083.

5. C. Wilke, N. Andersson, R. Van Fleet, A. Mathur and U. Germgard, Tappi Journal, 15, 167(2016).

6. D. V. Savant, R. Abdul-Rahman and D. R. Ranade, Bioresource Technology, 97 (9), 1092(2006), DOI:10.1016/j.biortech.2004.12.013.

7. S. Yao, S. Nie, H. Zhu, S. Wang, X. Song and C. Qin, Industrial Crops and Products, 96, 178(2017), DOI:10.1016/j.indcrop.2016.11.046.

8. S. Nie, S. Wang, C. Qin, S. Yao, J.F. Ebonka, X. Song and K. Li, Bioresource Technology, 196, 413(2015), DOI:10.1016/j.biortech.2015.07.115.

9. M. Gavrilescu, C. Teodosiu, D. Gavrilescu and L. Lupu, Engineering in Life Sciences, 8 (2), 99(2008), DOI:10.1002/elsc.200720236.

10. D. Gavrilescu, A. C. Puitel, G. Dutuc and G. Craciun, Environmental Engineering and Management Journal, 11 (1), 81(2012), DOI:10.30638/eemj.2012.012.

11. A. Bhatnagar, Rasayan Journal of Chemistry, 8 (1), 143(2015).

12. N. K. Swamy, P. Singh and I. P. Sarethy, Rasayan Journal of Chemistry, 4 (2), 452(2011).

13. M. Gergov, M. Priha, E. Talka and O. Valttila, Tappi Journal, 71 (12), 175(1988).

14. L. M. Jaacks and L. R. Staimez, Environment International, 76, 57(2015), DOI: 10.1016/j.envint.2014.12.001.

15. C. Qin, B. Liu, L. Huang, C. Liang, C. Gao and S. Yao, Royal Society Open Science, 5 (12), 181507 (2018), DOI:10.1098/rsos.181507.

16. K. Solomon, H. Bergman, R. Huggett, D. Mackay and B. McKague, Pulp and Paper CanadaOntario, 97 (10), 35(1993).

17. R. Orrego, Z. Pandelides, J. Guchardi and D. Holdway, Ecotoxicology and Environmental Safety, 74 (4), 761(2011), DOI:10.1016/j.ecoenv.2010.10.042.

18. CPCB, The Environment Protection Rules 1986, 445.

19. S. Nie, S. Yao, S. Wang and C. Qin, BioResources, 11 (1), 713(2016), DOI:10.15376/biores.11.1.713-723.

20. L. Yang, L. Fang, L. Huang, Y. Zhao and G. Liu, Green Energy \& Environment, 3 (3), 302(2017), DOI:10.1016/j.gee.2017.07.002.

21. D. Kaur, N. K. Bhardwaj and R. K. Lohchab, Journal of Cleaner Production, 170 (1), 174(2017), DOI: $10.1016 / j$.jclepro.2017.09.111.

22. J. Vehmaa and O. Pikka, In Proceedings of the Paperex, New Delhi, India (2007).

23. Laboratory manual for pulp and paper laboratory, NORAD-COURSE, Department of Chemical Engineering, The Norwegian Institute of Technology, University of Trondheim, (1993).

24. P. Kumar, S. Kumar and N. K. Bhardwaj, IPPTA - The official International Journal, 29 (2), 68(2017).

25. K. Ruuttunen and T. Vuorinen, APPITA Journal, 60 (3), 235(2007).

26. D. W. Reeve and K. M. Weishar, TAPPI Journal, 74 (6), 164(1991).

27. T. Y. Tsai, J. J. Renard and R. B. Phillips, TAPPI Journal, 77 (8), 149(1994).

AOX MITIGATION IN PULP BLEACHING EFFLUENTS 
RASĀYAN $J$. Chem.

Vol. 13 | No. 2 |1262-1270| April - June | 2020

28. M. Roy, S. K. Chakrabarti, N. K. Bhardwaj, S. Chandra, S. Kumar, S. Singh, P. K. Bajpai and M. B. Jauhari, Journal of Scientific and Industrial Research, 62 (7), 707(2003).

29. J. Morgan, A. Thakore and K. Krauza, In Proceedings of International Pulp Bleaching Conference, Stockholm, Sweden, 3, 271 (1991).

30. A. Bartzokas and M. Yarime, Technology trends in pollution-intensive industries: a review of sectoral trends, UNU-INTECH Discussion paper series 06, Institute for New Technologies (INTECH), The United Nations University, December, 9706 (1997).

31. S. I. Mussatto, G. J. Rocha and I. C. Roberto, Cellulose, 15 (4), 641(2008), DOI: 10.1007/s10570008-9198-4.

32. Q. Hong, N. H. Shin and H. M. Chang, In Proceedings of Pulping Conference, TAPPI Press, Atlanta, 1, pp. 63-69 (1988).

33. P. Li, Q. Hou, M. Zhang and X. Li, BioResources, 13(1), 450(2018).

34. R. Malhotra, Ph. D. Thesis, Department of Paper Technology, Indian Institute of Technology Roorkee, Uttrakhand, India (2006).

35. Environmental Management in the Pulp and Paper Industry, UNEP - Industry and Environment Manual Series, Industry \& Environment Office, United Nations Environment Programme; 1st edition, 2 (1981).

[RJC-5408/2019] 